IIUC STUDIES

ISSN 1813-7733

Vol.- 9, December 2012

(p 79-106)

\title{
Philosophy of Education in view of the pressing Muslim Requirement in the Islamic and World Perspective
}

\author{
Prof. Dr. Muin-ud-Din Ahmad Khan*
}

\begin{abstract}
In Islam education is endemic to humanity and to the Muslims talabul ilm, acquisition cum research, is imperative, whereas by being bounded within the four walls of husulul ilm, acquisition of knowledge, education of the present-day Muslims has became epidemic by dint of their enthusiasm especially for chewing the cud of the foreign nations in the name of modernization of education which practically throws the Muslim elites out of the global Ummatic social arena turning them into supplanted personalities. Hence, in order to catching up with the dynamic spirit of Islamic education the Muslims are required to suitably overhaul the mentality and aims and objects of education.
\end{abstract}

\section{Preamble}

In the light of the Quran, no sooner had Allah created man than gave him education in the science of identifying and naming things. The first revelation of the holy Quran urged the Prophet of Islam to read in Nature, to observe, to write, to calculate with a view to knowing the unknown, which is knowledge. This direction virtually covers all categories of knowledge in depth and level.

In sharp contrast, all sorts of conventional education now prevailing amongst the Muslims everywhere in the world, have become rather epidemic to the Muslim Ummah that throws up its educated hosts down-right into an uprooted firmament of supplanted personalities. In effect, whereas Islam wanted a universal education and a life-long search after knowledge by the Muslims, educated Muslim elites of today love to remain at safe-distance from the lowly Muslim masses, whom they themselves pushed aside by dint of their bad leadership and

\footnotetext{
* Dean, Faculty of Social Sciences, Arts and Law, Southern University Bangladesh, Chittagong
} 
gross love of foreign goods, foreign customs, foreign laws, foreign habits, foreign aids, foreign relief, foreign advice and high services of the foreign Companies.

Degradation, corruption, shallow legalism, aggressive altercation, fantastic irreligiosity and widespread elitistic gossip and a somewhat nostalgic uneasy feeling towards religion cropped up inside the Muslim social order and education system. The Nobel Prize winner Professor Abdus Salam delineated its causality as stiff staticness in the flow of life and education amongst the Muslims leading to ossification of thought and the spirit of seeking after truth, neglect to research and experimentation since about five hundred years back, about the 16th century Christian Era (C.E.).

The 18th century (C.E.) Muslim sage, Shah Wali Allah's clarion call to heed to the spirit of the Quran and the Sunnah and to clear off the debris of blind legalism as well as repeated warning of the Turkish sociologist, Zia Gokalp and of Iqbal, Shibli Nu`mani and poet Nazrul Islam at the turn of 19th and 20th centuries went practically unheeded. During the first half of the 20th century Syed Ameer Ali forcefully called the attention of the Muslims to the abiding modernity of Islam in an article entitled "Islam and Modernity " (K.K. Aziz ed. Life and Works of Syed Ameer Ali). He said, Islam wanted to spread enlightenment amongst human beings through universal education whereas the Muslims of the time refuse to accept it even when offered at their door-steps. He held out convincingly that Islam had remained still as modern as at the time of its nativity; it needed no reform but the revival of the spirit by which the Prophet was inspired. The words of the master have remained as fresh and as effective as when they were uttered, but the followers are unable to understand it. To break the ignoramus torpor of the Muslim masses and the vain-glorious selfgratification of the Muslim elites, he dedicated a full-dressed book The Spirit of Islam, which was more quoted than followed.

Deliberately keeping aside Syed Ameer Ali's proposition to give serious indulgence to the primacy and originality of Islam, the Muslim elites held conference after conference all over the world, nationally as well as internationally, aiming at reforming Muslim education system. They virtually let to pass nearly a full century in fruitless debates and enthusiastic deliberations for synthesizing the absolutely out-dated Madrasah system and half-a-millennium long outworn, deductive textbook bound explanatory (matan wa sharh) latterly Muslim education 
technique and teaching methodology of the Muslims with the post renaissance ultra-materialistic and naturalist Greek ideology-oriented modem philosophy- based Western education system. They little realized that the modern West had borrowed from Islam, the scientific methodology, which alone Muslims could take back and reunite it with their evidential experimental logic which the West did not touch (Origin and Development of Experimental Science, published by BIIT) and still remains intact amidst the piled up treasures of Islamic archives and books of wisdom such as Imam Ghazzali's Al-Mustasfa min ilm al-usul (Bulaq, Egypt, 1322 Hijri).

Instead of developing a brand new wholesome education system from the roots of the Quran and the Sunnah in pursuance of Quranicoriginated experimental scientific logic and methodology, they endeavored to synthesize the Occidental and Oriental education systems for the benefit of the modern Muslims. Consequently, there was a lot of miss-messing of spirit, juxtaposition of ideas and conglomeration of materials and at the long run neither of their twopronged efforts to promote the education of the Muslim community, one in isolation and the other in mixed-up, produced the expected result. Love's labour was enormously lost!

These arm-chair Muslim elitists hardly grasped the classical Muslim hadd and burhan-based experimental scientific spirit and over and above that, in order to be acceptable to all and sundry, they tried to make their synthesis unradical and easy-going. As a result, their recommendations were more art-oriented and less scientific. It opened up no fresh vista of vision to inspire the teachers and students nor did it enthuse them to start an academic movement in any way comparable to their exuberance in politics. They often forget that education is not cramming ideas in the mind and memory of the students, rather to train one to think clearly, creatively and rightly.

It is often given out by the Muslim elites and modernist Muslim ruling factions, everywhere in the world, that in order to bring out the Muslims in the bright day-light of modem civilization, they have introduced a modern education system in pursuance of the West. Their sole aim is modernization by all 
means. Yet, for the lack of spirituality and Idealism, they are gaining a merely imitative Westernization.

Yet whereas the Western education systems are science-oriented, the Muslim modern education systems are art-oriented. Our elites are unable to think that the Muslim scholars in the past built up or invented all sciences (ulum) and no arts what-so-ever with the solitary exception of Arabic, Persian, Urdu literature. On the other hand, Japan and China also introduced modern education in imitation of the West, but their education system turned out even more scientific in certain sectors than that of the West. Then who would ask as to why it is so? Whence arise the differences? From the respective systems (?), intention (?) endeavors? or faulty execution (?).

Last but not least, the Prophet of Islam (sm.) urged upon the Muslims to seek the knowledge from the cradle of the grave. But now-a-days all the world over, the Muslims are more illiterate in greater proportion than other people everywhere. The elites talk about it in response to the demand of Christian missionaries and foreign governments to fill up the continuous widening gap with their help. But no effective measure is yet in sight. The Japanese National Institute of Educational Research (NIER) has recently adopted the policy of devising a 'life-long education' system for the people; whereas we are still lingering with our staggeringly unfulfilled objective of education for all' set up before us by UNESCO since long. Present political awareness of the Muslim masses around nearly sixty independent countries of the world, could well be a reminder of a famous saying that, universal suffrage, without universal education, would be a curse,

We may close this foreboding by citing an example of the Qudrat-eKhuda Education Report of 1974 in Bangladesh aimed at (a) creating awareness amongst the students of the Sate ideology of socialism, democracy, secularism, and nationalism and (b) preparing them for fulfilling the national aspirations by their functional and professional 
education. In a word, it may be termed as 'useful education' in the language of W.W. Hunter. Hunter was appointed Chairman of the First Education Commission of British India in 1880. He submitted his report in 1882 with the Chairman's observations that the Indian education system " was a futile exercise to acquire useful knowledge instead of preparing the mind for creative thinking". That is to say, one hundred twenty years back, the learned circle of the West regarded, 'creative thinking' as the object of education and down-graded its mere 'utilitarian acquisition'. Measured by that old standard, the present-day educational system of Bangladesh that produces imitator graduates instead of creative thinkers, is that long out-dated. Indeed, in the Asian-African Orient, many civilizations have converged into one another and produced time-old full-blown social systems. In comparison, the Western societies are young and thriving with animation and half-bred ideas of conceptual philosophy. Consequently, every time the Muslim intellectuals set about reforming their education system during the last one hundred years, by way of synthesizing the cultural lores of the East and West, they invariably turned it less efficacious, less effective and even least world-widely competitive. Keeping the above practical insight in the back of our mind, we may set out to delve into the matter of Muslim education lock, stock and barrel.

\section{Nomenclature}

Education implies imparting lesson, learning and knowledge by the expert to the novice by means of mental and spiritual equipment; such as ideas, concepts, thinking and speech. But the literal meaning of 'education' as a Latin word, falls much short of this implication.

The Latin-based word 'education' is derived from educo, educatum. which basically means to lead forth, to bring up, 'to rear, to instruct and remotely means to advance the mental, aesthetic, physical or moral development of, esp, by teaching or schooling, (The Lexicon Webster Dictionary .Vol. 1, 1983, p. 313). Education, however, philologically means 'training', such as training a horse. Literally it is , therefore, not comparable with the Bengali-Sanskrit words shiksha and diksha (শিক্ষা ও দীক্ষা) and the Arabic ta'lim and tarbiyat (তালীম ও তরবিয়াত) which are applied alone on human beings and never on animals. Nevertheless, by implicational usage 'education' has latterly come to be used as the equivalent of its Arabic and Bengali counterpart of Shiksha and ta'lim. Yet, the conjugational part of diksha and tarbiyat which stand for 'moral preparation for proper education' is missing in the connotation of 'education'. Because, in the 
Oriental concept good conduct and refined manners are pre-condition of good education.

The Oriental concept of education is wedded to the training of manners and morals, the right conduct, etiquette, humility and overall good living which are implied by diksha and tarbiyat and when such trainings are willingly and voluntarily received. Amongst the Western Christians, this is imparted by the priest and not by the teacher as 'counseling'. In the East, it is generally held that education, without the proper training of manners and morals, produces unbridled power, daitya,giant, demon rather than well-mannered learned person, wholesome man or woman and a man or woman with well-round personality.

Realizing the above differentiation, the Westerners have begun saying that animals can only be trained but cannot be educated although the original meaning of education, educo and eductum, is training. Even so, they hold that 'knowledge is conceptual' as Socrates said it in the early stage of his career. Yet Socrates latterly realized his mistake and propounded the motto

"Know thyself"; that is, self-knowledge, which he was unable to propagate as he was soon killed by the representative Assembly of the Athenians, who condemned him to die by drinking (he juice of poisonous hamlock for the offense of propagating the doctrine of pure religion amongst the young, people of the pagan idol-worshiping Greek society. This motto was an exact translation of the Sanskrit dictum : atmanong bidvi (আত্নनংবিদ্বি) which is a piece of Vedic philosophy propounded forcefully in "Mandukya Upanisada", which, however, is extended from self-knowledge towards the knowledge of the Supreme Lord : Brahma Gnana (ব्रহकाष्छान). Thus, self-knowledge leads to God's knowledge, the knowledge of God.

In this context,we are reminded that, wisdom in the West-comes from philosophy, the Greek sweet-heart " philoe sophia (gnanpriti : love of knowledge), which, in the Orient, falls in line with the third digit of knowledge tatva gnana (उত্ত্তष্ঞান). Whereas in the Orient wisdom flows from practical experience, at the fourth digit of knowledge, called ma'rifat, in Arabic and turja in Budduttar aagam Shastra and divya gnana in Vedic Sanskrit. No wonder, therefore, we hear of Oriental wisdom and Western statesmanship. Wisdom seems to have been borrowed from the East by the West. Hence, while the Westerners 
speak of the 'philosophy of education', the Easterners speak of the 'systems of education'. We might, however, speak of a 'basic concept, underlying a given system of education and loosely call it 'educational philosophy' rather than the umbrella concept of 'philosophy of education'. Our object is to mean principles of education and the philosophy behind a given system of education.

For instance, in the classical Chinese world-view 'human nature' is conceived to be radically 'good', which may be corrupted not by a breaking out of an internal taint (or propensity), but by external infection (cf. Encyclopedia of Religion and Ethics, 1981. Vol. 5, P. 183). Hence the orthodox Chinese education system endeavored to preserve the 'naturality' of man and to protect him from anti-natural influences. Whereas the Vedic and Buddhistic education system endeavored to elevate man above the lower nature of the natural propensities and to draw him nearer to the higher self; the devine nature of man, the soul. Nevertheless, all the Oriental systems of education are objective, truth-oriented vis-a-vis Western systems, which are subjective, ism-oriented, ideal or ideology-oriented and befoolingly they often speak of ideals (in the Platonic sense) and soon enough reduce their ideas to ideologies (in the capitalist or socialist mould) and turn their ideologies to philosophy and philosophy to isms, which are in fact individual broodings of great thinkers.

\section{Definition and Aims: The Western Perspective}

If we begin our deliberations with 'education' and apply it for mankind, it would certainly require a definition of the Western type; that is to say, responding to the Aristotelian question of'what (it is called)? visa-vis the Oriental question of what (it is)? Nominalistic versus realistic question of What is. What of what, as it is called in the Holy Qur'an: ma. adraka ma hiya? That is, going one step forward to say, What makes it what it is?

If we ask then: What is education? Its answer would descend upon the matter, carrying the literal meaning of 'rearing' with it, but by convention, aspiring to impart mental ideas or exchange views. Hence, it would need he conceptualized with a definition setting forth its aims and objects. But if we start asking: what is Shiksha or ta'lim(?), in the Oriental sense, and look forward towards its complimentary counterpart of diksha or tarbiyat,, it would lead us to a processual base. In that case, we may simply describe education as "the process through which older people endeavour to pass on to the younger 
generation their hard earned ideas, fruitful experience and practical wisdom with a view to render it easier to the latter to face the problems of life and to aspire for a better world" (adopted with modification the view of Compton's Encyclopedia, vol.7, 1986, p.74). In similar view, the Encyclopaedia Britannica describes, "Education can be viewed as the transmission of the values and accumulated knowledge of a society". Likewise to some of the Westerners "Education includes all the forces that influence human development." According to others, as it is limited lo something so narrow as to be equivalent to nothing more than teaching" (Ency. of Rel \& Ethics, 1981, vol. v, p. 166).

The Westerners, however,view education as bound up with the human development, improvement of life and attainment of happiness in this earthly life alone vis-a-vis the Oriental religious outlook of viewing education as a potent means of attaining happiness in this mundane life as well as in the life hereafter. For instance, Plato amongst the ancients regards the main intention of education as to teach (worldly) virtue all through man's life from birth to death (ibid. P.186).

In the classical modern age John Stuart Mill says that education "includes whatever we do for ourselves and whatever is done for us by others for the express purpose of bringing us nearer to the perfection of our nature. The 'nature' concept was further developed and elaborated by the modern Western idealists, such as, Pestalozzi, Froebel, Kant and Hegel, who generally regarded man as though constant in personality, yet always progressively developing. They compare human child with a plant: "it can grow and develop, it is growing but in a determinate way; true education, therefore, must aim at permitting and encouraging the child to develop in the greatest possible freedom " (ibid. pp. 166-67). They then bring into play the deliberate purpose to help develop by means of modifying the process of development with the least interference with the child's growing nature 'by means of knowledge systematically imparted' (ibid.). Hence, connotatively education brings forth four dominating ideas viz. (a) education (b) instruction (c) teaching and (d) self-realization (ibid). 
As regards education as a wholesome design, the Encyclopedia of Education (Torsten Husen et al ed., Oxford, 1985, p. xiii) says that, education is a continuing process throughout life. However, as a science or an art "it includes mainly formal experience designed to provide the young with knowledge, skill, attitudes and values for competence in future roles as individuals, citizens and workers". It also concerns with the educational needs of adults in all their roles as workers, spouses, parents, citizens in social and working life, in retirement as well as with the individuals seeking personal development.

The above Western modern trends of thinking in this field have instilled into the modern education a multidisciplinary nature which has given rise to various theories methods and practices in different countries and nations. In this respect the U.K. system is said to be largely pedagogic laying emphasis on grammatical norms and historical tradition. The German system is generally described as operating in pursuance of an idealistic, humanistic, paradigmatic framework largely in the light of the philosophy of Wilhelm Dilthey (1833-1911) that lays emphasis on inventiveness of unique goal-seeking individuals (ibid.)

On the other hand, the United States, in collaboration with the Scandinavian countries, lays greater emphasis on psychology in building theories, devising methods and putting them into practice in conformity with the popular philosophy of pragmatism.

Yet another trend of thinking about education in the West has grown out of the impact of modern science. It is of "an experimental nature following the paradigm of the natural sciences. It combines both pragmatic and empirical traditions and emphasises on child development cum learning as well as attempts at measuring human intelligence by means of quantitative surveys, statistical and applied psychological methods (ibid.). 
All these Western view-points regard man as a part of nature and long for finding what Nature intends for the children as well as the growing individuals and to follow that up. It says: Only by rightly guiding the pupil can the master himself be right. If the boy`s nature and the master's (nature) are each developing freely, then their actions must of necessity fit into each other and produce a harmony, erstwhile inherent rationality of the wholesome universe (ibid. p.161). It generally leads to free society.

Being conjured by the term 'education' the Westerners introduce the assumptions of 'capacity' along with the acts of training and instruction (educo) and make a distinction between simple instruction and educational instruction. They hold in this context that animals cannot be educated, but can only be trained (ibid. p. 170).

The above unilinear naturalistic notions of man in nature as a part and parcel of it, represents a naive or artless-pre-Socratic and post-Renaissance conceptual point of view. Therein the latterly Socratic deeper insight regarding 'know thyself', of the self knowledge corresponding to the Sanskrit Upanishadic 'atmanong bidvi' was completely overlooked, and as we have shown elsewhere (The Origin and Development of Experimental Science, BIIT, 1997), it emanates from an empirical philosophical ground of erroneously regarding sense-perceptual knowledge as itself knowledge (knowledge per se), rather than raw material of knowledge.

In the view of the Orient, instead of it, 'man confronts nature,' man is not merely a part of Nature, but above that, man has a discretionary power and a utilizational prowess over all natural objects. Man's relation with nature is not so simple; rather, it is complex, wherein man stands confronting nature with power and responsibility. Secondly, it discloses a definitional attitude of knowledge which is untenable in the Oriental point of view, since definition or sanga 
(sangya) is useful in naming an object but is useless in delineating the function and activities of it. Thirdly, the science of definition is an acquisitional type of learning in the literal sense, which is called bidya in Bengali and Sanskrit and ilm-i-kasabi in Arabic, pointing to Gnosis in Greek and Gnana (জ্ঞান) in Sanskrit ( $($ $=ম হ=জ ্))$, meaning real knowledge.

Therefore, the definitional process of Aristotelian logic or its other correlates, would lead us nowhere in our search for a potent educational system suitable for our times for the Oriental peoples. Simpleton simplicity, naivity, superstition and rigidity of all kinds are to be avoided, if we are to face the real problems of a complex life.

\section{An Objective Question of What?}

Instead of asking the Aristotelian definitional question of what (it is called)? if we ask an Oriental question of what it really is ?; that is to say, what education is? It will ipso facto take us to the pros and cons of it; to the origin of human species and the spring of knowledge and education, on the one hand, and to the latest contemplation in the area of human tradition, culture and civilization, on the other. Thereupon, we may draw our mental agility back and forth to size up the process of the development of education from time to time, and clime to clime, to arrive at a reasonable, well-balanced and comprehensive idea of education as a means of modeling the life and thought of human beings throughout the world, as per human being. We are to be constantly reminded that the human nature comprises two mutually opposing aspects, which we realise, in the depth of our experience, as the urge of desire or propensity versus the bid or urge of conscience.

All through human civilization in the Orient, these urges have been recognized as lower animal nature and upper divine nature of man. Totally engrossed in the speculation of ideas and unattentive to the actual experience of human life, this dichotomous nature of man did not properly crystallize in the tapestry of young and thriving Western civilization. We must not, therefore, sacrifice human conscience of the Oriental civilizations at the altar of animal desires of Western civilization. 
Hence in search of such an objective and meaningful education, we step upon three types of educational systems at three slightly different levels of human life. These are (a) historical, (b) rational and (c) spiritual.

\section{a. Historical Perspective of Education}

From what tit-bits of evidence available to us regarding the ancient Orient, it has been calculated by the scholars that, in all primitive societies some sort of education was present, which took the form peculiar to the prevailing tribal, racial, caste, colour or even class consciousness and the ideals entertained by the people concerned. For instance, in China education became a media of maintaining tradition and promoting ancestor-worship in ancient times; in the Middle East, at early times, education followed the astral worship, political influence and commercial transaction; in India Brahmanism and caste polution became the dominant features, dualism in Persia, practical wisdom in China, and else where 'king-worship and common sense had their respective marks along the lines in which education developed.

Probably the earliest sign of a systematic educational instruction we come across, was at Mesopotamia of the ancient Iraq around 2000 B.C. as deciphered by S.N. Kramer: (Journal of the American Oriental Society, vol.69, 1949, p. 199 ff. "School days, a Sumerian composition relating to the Education of a Scribe"), which runs as follows:

"Schoolboy where did you go?" "I went to school". "What did you do in school?" "I read my" tablet, ate my lunch, prepared my tablet, wrote it, finished it, then upon the school's dismissal, I went home entered the house, (there) was my father sitting. I spoke to my father; read the tablet to him,, (and) my father was pleased; truly I found favor with my father. (I said) I want to go to sleep; wake me up early, in the morning; I must not be late, (or) my teacher will cane me. When I awoke early in the morning, I faced my mother, and said to her; 'give me my lunch, I want to go to school'. My mother gave me two rolls. I went to school. In the tablet house, the monitor said to me; "Why are you late?" I was afraid, my heart beat fast, I entered before my teacher, took (my) place. My school father read my tablet (and) caned me. The teacher in supervising 
the school duties, 'looked into house and street in order to pronounce upon someone, (and) caned me. (He) who was in charge of the drawing (said); "Why when I was not here did you stand up (He then) caned me. He who was in charge of the gate (said); "Why when I was not here did you go out? "(He then) caned me." (cf. Edna E' Kramer: The Nature and Growth of Modern Mathematics, Princeton University Press; N. J., U.S.A., 1951, P.1).

With a view to getting rid of the torture of caning, the family arranged for the entertainment of the teacher. Being pleased at the end: "The teacher with a joyful heart gave speech to buck him up, "Young man, because you did not neglect my word, did not forsake it, may you reach the pinnacle of the scribal art, achieve it completely. May Nidaba, the queen of the guardian deities, show favor to your fashioned read. Of your brothers, may you be their leader. Of your companions, may you be their chief, may you rank the highest of (all)' (ibid.).

For appeasing the teacher further, there is a hint at engaging him in extra-curricular tutoring as it has now-a-days become rampant in our country. It is often said that civilization grows and changes fast; but culture persists. For, civilization is time-bound and culture is timeless, value-oriented.

Perhaps, since more ancient times, education was considered as an important matter in China. The Encyclopedia of Religion and Ethics (vol. 5, p.183), states that, since time immemorial kings and people of China laid greatest emphasis on education. Kings themselves started with education and schools. They believed that human nature was originally good and without education his nature deteriorates. The aim of education was "the formation of character so as to fit a man to play his part in the society and more particularly in the State employment."

The Chinese divided human beings into four classes, viz. Scholars, agriculturists, artisans and traders and amongst them the scholars took precedence. Chinese morality demanded that "a scholar may be killed but cannot be disgraced", "The scholar learns extensively but never allows his researches to come to an end."

The scholar, when he hears what is good tells it to his friends and when he sees what is good, shows it to them. "Gentleness and 
goodness, respect and attention, generosity and large mindedness, humality and courtesy, the rules of ceremony, singing and music" were the subjects of study and matters of acquisition, "These are the qualifications and manifestations of humanity".

The scholar possesses all these qualities in unison, yet on account of them, he will not venture to claim for him a perfect humility. "Such is the honour he feels for the ideal and for humanity, with which he declines it for himself." The scholar is not cast down or cut from his root, by poverty and mean condition; nor is he elated or exhausted by riches or noble condition; hence he is styled as scholar" (cf. Li Chi xxxviii, 3-9).

Since very ancient times, there was a Minister of Instruction in China. His function was to teach the multitudes all moral and social duties, how to discharge their obligations to men living and dead, and to spiritual beings" (cf. S. B. E. xxvii, 23 In.). We can imagine the means and mode of his instruction from the Analects recording the intercourse between the great sage Confucius and his disciples.

"At the 2oth year of his age Confucius taught all who, attracted by his reputation, were willing and able to receive his instruction, however, small the fee they could afford. His school was peripatetic (that is teaching while walking along the garden as was done by Aristotle in later times at Greece), and the teaching was conversational."

"His themes were Book of Poetry, Book of History, and the maintenance of the Rules of Propriety. He taught ethics, devotion of soul and truthfulness." In the case of his disciple Mencius, we hear of education from pre-natal behaviour of the mother, home-training and school teaching."

At the time of Han dynasty (Han Wen-Kung 768-824 C. E.) we hear of flourishing government schools, Chao-Chow Prefecture and the examination system for choosing suitable personnel for State service. Education started there at 7/8 years of age and were gradually taught what was popularly known as eight-legged-essay.

Hanlin Papers ( $1^{\text {st }}$ series p. 58) say : " a ripe Chinese scholar is in knowledge a child, in intellectual force a giant, his memory is 
prodigious, his apprehension quick and his literary matters exquisite" (ibid. p.184).

In ancient times Buddhist system of education was also lessonable and instructive. For well-calculated reasons, Buddhism, as a way of life revolved round Monasteries. Hence Buddhist system of education was elaborate and monastic.

In quest of knowledge, the Chinese traveller Fa-Hien (400-450 C. E.) visited Pataliputra (Patna), Tamralipi (Tamluk in West Bengal), the Punjab and Ceylon (Srilanka), Nala, Nalanda (Gaya). He found that the Buddhist instruction was oral and imparted by the words of mouth. But in the further East (Indonesia) Vinaya and Abhidhrma were imparted from written texts.

Another Chinese Traveller, Hiuen Tsiang visited India (629-645 C.E.) and went to Central Asia. He also visited the important Buddhist education Centres at Ceylon and Nalanda. In the later part of the century C.E.,Chinese Traveller I-Tsing visited the Buddhist empire Srivijaya (Indonesia).

From their travel reports we come to know that: (a) The course of instruction for boys began at 10 years of age, with the study of grammar, which was a three-years' course,(b) Reading of Commentaries; and works of more advanced character on grammatical science, logic and philosophy committed to memory followed. This was meant for both layman and devotee (c) The devotees further studied works on Vinaya with the. Sutras and Shastras. (d) The Treatises on Abhidarma were also made the subject of study at higher stages and public discussions were held at which heretical opinions were taken into consideration and refuted. In the ancient West, the Greek trading nations received the contagion of the pursuit of education by coming into close contact first with the Phoenicians, then gradually with Iran, Mesopotamia and Egypt. It was an isolated case in Europe. Her educational endeavor was, however, highly restricted.

In ancient Greece, individual had no separate existence apart from the State. Hence education to the Greeks was meant for preparing the individuals for the benefit of the State. The aims and objects of human being were completely subjugated to the ideals of the State. State was above all and nothing was above that. It was secularism, pure and simple, which guided the steps of the Greeks. 
Therefore, the subjects taught were classed under two heads: music and gymnastics, corresponding generally to literary and physical training. As such, the training of citizens fell into four periods: (a) childhood: up to 7 years of age (b) boyhood: public training school 8 to 18 years (c) youth: training of war; over 19-30 years and (d) practising what they were trained to do (cf. Ency. of Rel. \& Ethics, vol.5, p.172).

The Sophists were the intellectuals of the Greek society. They are regarded by the above authority as "teachers rather and educators." It is said that, "they professed to communicate a certain amount of valuable knowledge rather than to form character" (ibid).

Moreover, the Greek education was closely related to the Greek idea of citizenship. Hence education was restricted to the free population possessing full civic rights (ibid. p.1.286). Nevertheless, Socrates attempted to introduce virtue into education and Plato regarded "to teach virtue as the main intention in education and man's life from the birth to death, to be one round of instruction and admonition (ibid).

As a matter of fact, the free citizens who controlled political power were less than half in number. In Athens, the citizens counted about one-third of the whole population, the remaining two-third being slaves and aliens who were deprived of all rights and facilities.

In India, education was a matter of highest devotion and dedication of life. The Vedic and Brahmanic education was, however, restricted. Education was the special prerogative of the Brahmins and consisted of recitation of hymns and memorization of Vedas and Commentaries. Latterly the high caste Kshtriyas were allowed to read and write; but they were not allowed to touch, read or even hear the recitation of the Vedic hymns. For their entertainment story-books, Puranas, dramas and even great epics like Mahabharata and Romayana were composed. Yet the lower castes and outcastes who formed the overwhelming majority of the populace were discouraged to read and write and even prohibited to hear sacred recitations on sufferance of severe punishment.

Nevertheless, the Brahmins and Kshatriyas maintained an high standard of education and enlightened culture within a narrow restricted circle. Buddhism was a revolt to it and the Muslims, having conquered India, opened the gate of education to all and sundry. 
All these attempts at developing suitable educational facilities and systems in ancient times, were prompted by the respective philosophy of the peoples concerned and their enthusiasm to promote discipline, peace, prosperity and happiness in life. Only on one point their thoughts were in unison, viz. all of them regarded themselves as a part and parcel of Nature and they earnestly, endeavored to fit in themselves along with the remaining objects of the universe in the harmony of Nature merely as superior animals; rational animals, political animals, economic animals, speaking animals and so on. In one word, they felt themselves as man in Nature'

\section{b. Rational Perspective of Education}

During the medieval period of Europe, as the Greek philosophy combined with Roman political domination and Christian religiohumanitarian ideology to produce the Christian world-view and Christian theology, the education system was radically changed. It came to be known as medieval scholasticism or the Roman system of education. It was formed by seven Liberal Arts - divided into two groups of subjects, viz: Trivium and Quadrivium. The Trivium Arts consisted of Grammar, Rhetoric and Dialectic or Logic; and Qiiadrivium Arts were Geometry, Arithmetic, Astronomy and Music. These were developed by Saint Augustine and Capella the Carthaginian.

Side by side, the Monastery systems which gradually grew into Universities under the impact of the Islamic influence had entertained seven free Arts, e.g. Riding, Shooting, Hawking, Swimming, Boxing, Chess-playing and Verse-making (ibid. p. 172).

The above authority contends that a similar position continued to flourish in the West till the time of Renaissance, which divided the scholars into three groups, viz. (a) Humanists, who leaned upon words, (b) Realists, who leaned on things more than on words; and (c) Naturalists, who laid less emphasis on mere subjects to be taught and more emphasis upon the training supplied by life itself. They aimed at, not so much to teach this or that subject, but really at bringing the pupil into direct contact with life at the proper points and thus enable him to work out for his own.

We must, however, be reminded that the Western pursuit for knowledge still remained skin-bound with conceptual knowledge, that is bidya as we say in Bengali, moving around in the world of ideas, far above the 
practical experience, the world of actualities or tajribah (in Arabic) whence arose the experimental methodology of Muslim sciences.

We come to know through more comprehensive later research of Gordon Leff (Medieval Thought, St. Augustine to Ockham, Penguin,1958,1965), that independent philosophical speculation in the Roman empire came to an end with St. Augustine (354-430 C.E.) and his disciple Boethius (470-525 C.E.) whose pupil Cassiadorus founded a monastery in South Italy known as Vivarium. He formulated the dual system of Divine and Secular literature viz. Trivium and Quadrivium. The Trivium dealt with the three subjects of grammar, rhetoric and logic and the Quadrivium with the four sciences (sic!) of arithmetic, astronomy, geometry and music (p.50). In fact Martianus Capella, from whom Boethius had drawn his Quadrivium wrote "a hand book on the liberal Arts grouped into three and four". The word science came into use in England about the middle of the $19^{\text {th }}$ century C. E. (as we have conclusively shown elsewhere). Gordon Leff says: "This was the foundation of Cassiadorus's own educational principles, and through him and his (above) predecessors they formed the basis of learning throughout much of the Middle Ages" (p. 51).

With the eleventh century, "medieval society". Leff says, "began to come into its own. The following cultures present an almost new world in comparison with the past" (p.62). In fact, the 12th century, the Crusading Century (Crusade ended in 1204) played the role of a catalyst in the cultural history of Europe; it opened a flood-gate of dazzling Islamic civilization to the West; and before and after that, thinking, ideas, education and culture were never the. same".

To quote again the above authority; "Yet this contact with the Moslem world by Crusade, pilgrimage and trade had a fruitful influence upon the West, it introduced it to a higher civilization and helped it to regain the full heritage of Greek culture as well as the riches of the Moslem world. Without these sources scholasticism would have had a very different history and probably an incomparably poorer one. Just as the West was dependent on the East for so much of its trade and luxuries, it owed it a debt also for its civilization" (p.86).

Indeed, this latterly debt of culture and civilization was enormously larger than the former. They gained the new life-blood of culture and civilization in the form of the University System of education and 
Experimental Sciences from the Muslims, which they found readymade in the reconquered Institutions in Sicily and Spain.

He further says: "The Universities themselves were another creation of the Second Medieval Age". That is to say, this catalyst ended the first medieval Dark Ages of Europe and gave birth to a Second enlightening Medieval Age wherein the old Monasteries and Castle schools gradually turned into Universities by imitation of the Muslim higher Madrasahas, Jamiahs and Shamsiyahs (the Observatories cum Laboratories).

He says: "In thought, the eleventh and twelfth centuries were the centuries of re-wakening everywhere (in Europe). Whatever the subject, and whatever the region, there was a universal sense of discovery" (p.89).

"Intellectually, the difference between the twelfth and the thirteenth centuries was at its broadest, the difference between isolation from the Islamic world and contact with it. Islam provided the West with the twofold benefit of Aristotle's work and of its own philosophical systems. Both were of inestimable importance for the development of Western thought in the thirteenth century" (p. 141).

Confined to seven liberal Arts, the people there knew nothing of 'sciences'. They had no idea of research methodology or experiment. They had very little idea of logic, philosophy, medicine, literature, and religion. They had turned the Semitic Christian religion of One Supreme Lord into a superstitious (Devalogy, $>$ Dieu $>$ Theo=) Theology, which actually means Devatatva in Bengali and Sanskrit. In their seven liberal Arts, they were pursuing a sort of speculative logic.

Gordon Left says, "From an intellectual point of view they [Monasteries] represented the older tradition, their approach to theology was still by meditation rather than by dialectics" (p.89). Dialectics, indeed, they borrowed from the Muslim Kalam, Islamic religious philosophy, that deals rationally the Articles of Faith.

The transition of early Medieval Age to the later Medieval Age, which is regarded as the first Renaissance of the West, marked a passage from the speculative logic to rational logic. Hence, the subject of study 
profusely borrowed from the Muslim world was divided into Arts and Philosophy and Philosophy, in its turn, was divided into rational philosophy, and natural philosophy, which was, in fact two branches of the borrowed Philosophical and Experimental Sciences taken from the Muslims.

But they did not understand the real import of Experimental Sciences yet, since they took only its experimental methodology without the evidential logic (burhan) on which it was based. They further mixed up experimental science, which they called natural philosophy, with he inductive logic of the Greeks and continued to call it philosophy till after 1830 C. E. (as conclusively shown by us elsewhere). Consequently, Experimental' Science has become devoid of spiritual and moral imperatives and has turned into a tool of exploitation and of prosperity of a few and destruction of many.

\section{c. The Spiritual Perspective of Education}

In the historical perspective, we have seen 'man in Nature' as a part and parcel of it, wherein man roamed about in the world, seeking his proper place in the midst of other creatures. In the rational perspective, a modern man regards himself strugglingly disposed against Nature. He regards Nature as a hostile entity putting him into a perpetual struggle for survival. The former regards 'man in Nature` and the latter 'man against Nature'. In contrast, the great religions of the world, namely Zoroastrianism, Vedas, Judaism, Christianity and Islam regard man as 'confronting Nature' with power and responsibility. All of them propound a 'purposive creationism'. According to all of them, in the process of human creation, education was next to life. The Lord created man and taught him the science of naming all things (The Bibe of the World, edited by Robert 0. Ballow, N.Y., 1961,p. 561: Zend Abesta, p.644: Genesis; and Al-Quran, Surah Baqarah 2:31-33). By means of most ordinary experience we realise that. Nature made man physically tender, beautiful, attractive but weak and made him mentally strong.

Hence, man has to protect his body and life by his mental equipment of thinking, feeling and mental expression, that is, speech. Thinking, revolves round perception, ideas and concept objectifies in names, which is (the function of mind; whereas the mental expression crystallizes in speech. And the sum-total of thinking, feeling and speech is education. The latest of the scriptures, the Quran, clearly 
states that soon after creation, Allah taught Adam, the science of naming things (ilm al-asma'a).

Education is, thus, a basic equipment for the preservation and promotion of human life as well as for the transmission of ideas, tradition, culture, wisdom mutually amongst themselves and also more importantly, of heritage to the progeny. The end result is culture and civilization, which turn human animals into rational beings.

The creationist point of view also introduces a third element of 'soul', which is superadded to the mind-body complex of man. It is held to be specially breathed by the Lord into the human heart, which endows man with the Vicegerency of the Lord Himself. It makes man a unique creation: a superior rational being on the one hand and the spiritual representative or Vicegerent of the Lord, on the other. As rational being he dominates all the creatures of the universe by means of the education of sciences imparted to him by the Lord and as Vicegerent he judges freely between good and bad while utilizing them to satisfy his needs.

Thus, his power is wedded with responsibility. According to the Scriptures, the Lord made power and responsibility mandatory to him subjecting his ultimate future to a Final Judgment in a new eternal life after death, whence emanate morality and religion along with the power roles in this present mundane world of society and politics. Thus, the human life is juxtaposed between the two poles of religion and politics.

To contemplate from the known to the unknown, let us be reminded that in ancient Greece, the pre-Socratic knowledge was based on speculative or meditational logic; while the post-Socratic, Platonic, specially Aristotelian logic, was syllogistic, inductive and deductive, in reality rational, based on articulated and systematic reasoning.

The holy Quran brought in its train the 'evidential logic' based on objective reality, which was called, burhan. Ibn Sina, the great Muslim philosopher, held that the function of logic is to help one to reach the reality of hadd and the reality of burhan, haqiqat-ul-hadd wa haqiqat-ul-burhan (cf. Islami Bishwa Kosh: Islamic Foundation Bangladesh, Vol 4, p. 195-205).

To amplify the matter, it may be said that, in the process of human knowledge from end to end, the bodily needs are fulfilled by speculative logic, and mental needs by rational logic and moral and 
spiritual needs by the evidential logic. The Islamic system of knowledge, as it developed from time to time, from century to century, by assimilating previous heritage,borrowal from conquered alien traditions by and large by means of internal creative efforts, which gradually brought into full play all the three logical equipments in proportional combination to make up the warp and woof of Islamic culture and civilization.

The speculative logic was two digital: subject and predicate oriented, profit and loss thinking; rational logic was three digital: syllogistic major, minor, consequence-oriented heading towards definition; and evidential logic, in comparison, is four digital: riwayat, dirayat, jarah or tajrihah, and tadil,, meaning collection of information, examination and classification of data, experimentation, justified synthesis or conclusion, oriented to experiment.The last helped develop the Experimental Methodology of Science (conclusively demonstrated in our "Origin and Development, of Experimental Science" published by B.I.I.T.)

In pursuance of the three fold logic and threefold methodologies of learning and knowledge (bidya and gnana in Sanskrit and Bengali, alilm a1-kasabi wa '1-ilm al-ladunni in Arabic), the Muslim. Scholars in course of time developed a four tier education system with the Quranic inspiration of seeking after knowing the unknown (ma lam yalam), in Baghdad, Cairo and Cordova, which was assiduously imitated by the modern West as depicted below:

\begin{tabular}{|l|l|}
\hline \multicolumn{1}{|c|}{ Muslim System of Education } & \multicolumn{1}{|c|}{$\begin{array}{c}\text { Modern Western } \\
\text { System of Education }\end{array}$} \\
\hline $\begin{array}{l}\text { 1. Iblidaiyah consisting of three 'r' writing, } \\
\text { reading and arithmetic (kitabat-matan- } \\
\text { hisab), It varied from } 3 \text { to 5 years. }\end{array}$ & $\begin{array}{l}\text { 1. Primary: consisting } \\
\text { of three 'r', correct- } \\
\text { reading,-writing and } \\
\text { arithmetic. }\end{array}$ \\
$\begin{array}{l}\text { 2. Awwaliyat, the First Courses of Studies } \\
\text { consisting of grammar, rhetoric } \\
\text { andprosody(saraf,nahu,fusahatwabalaghat), } \\
\text { demonstratively teaching in the fields of } \\
\text { literature,Quranic text and exegesis, Hadith- } \\
\text { text, and sharh or critical analysis; elements } \\
\text { of principles, of }\end{array}$ & $\begin{array}{l}\text { Grammar School 'O' } \\
\text { level. }\end{array}$ \\
\hline
\end{tabular}


sifting information, such as, riwayatdirayat-Jarah-ta'dil; Hadith or Fiqh and Jurisprudence, rhetoric, prosody. Lcssions From elements of philosophy, logic, sciences (hikmah and mantiq) and correlative subjects. It covers the present dakhil, alim, fazil and kamil of Bangladesh. It absorbed 6 to 8 years.

3. al-ulum al-nazariyat'. the intellectual sciences, i.e. rational sciences. This section was probably called al-fadil or fazil, meaning 'honors' 'graduation'. It began with logic and mathematics, and proceeded through two types of Logic. Aristotelian syllogism and Islamic evidential' together called tarif and hadd on the one hand, an hikmat or elements of experimental sciences along with arithmetic, geometry, algebra, reaching out towards philosophy and dogmatic (falsafa and aqaid and kalam). Kalam was translated by the Western scholars as dialectics and is equivalent to Western theology (Devatatva). It may have covered four years or more.

4. al-ulumal-tajribiyah: Experimental Sciences wherein all branches of subjects were experimentally taught. It covered comprehensive study of any one subject, such as, al-ulum al-tabiyah (Physical Sciences), al-ulum al-kimiah (Chemistry), al-tibbiyah (Medicine), al-falsafah (Philosophy), ul-ulum as-siyasiyah (Political Sciences). al-ulum al-diniayah (Religious Sciences), ul-ilm at tarikh (Science of History) and so on so forth. It aimed at a comprehensive study of any one subject and attainment of mastery over it. 2b. Higher Secondary Grammar School: 'A' level

3. Graduate courses both ordinary and Hons. : Teaching of these subjects is calculated in the West as dealing with collection of material and and integration' of ideas, resgarding the arts and sciences taught in this stage, which ordinarily deals with isms and theories. It covers 3 to 4 years in the West.

4. This fourth stage is devoted to 'collection and integration of sourcematerials' derived from all possible sources. It aims at a comprehensive study and mastery over any one subject and is called Master's Degree. 


\begin{tabular}{|c|c|}
\hline $\begin{array}{l}\text { 5. Over and above the four stages, there was } \\
\text { arrangement for. research studies, which } \\
\text { involved more than one subjects. Hence } \\
\text { those who attained proficiency in research } \\
\text { was conferred the title of Allamah. }\end{array}$ & $\begin{array}{l}\text { 5. This research degree } \\
\text { was translated into } \\
\text { Latin as Doctorate or } \\
\text { Ph.D. i.e. Doctor of } \\
\text { Philosophy. }\end{array}$ \\
\hline
\end{tabular}

\section{Factual Observations:}

The above evidences draw our attention to the fact that Islamic education system was an ever-growing dynamic process. It started with the clarion call of the Prophet of Islam to seek knowledge from the craddle to the grave; and in course of time, proceeded to the evidential logic. The Muslims formulated the basic dictum of al-ibratu bil-khwatim, i.e. in education the last or the end products come first, a tree is known by its fruit and, the lessons about it proceed from the fruit to the root in order to discover what the thing really is. It points to the' real quality. The second step consists of quantitative measurement (haqiqat-ul-hadd) by the estimation of its length and breadth, warp and woof. The third step is formed by experiment (taribah or jarah) which delineates its function and classification; and lastly the fourth and final step reaches out towards the origin and development of itself. The end-product of knowledge and experience being always in a flux, the Islamic education system has to ceaselessly grow and move forward. It can never be at stand-still.

In respect of religious sciences first counts sciences of the holy Quran, in particular Tafsirs, science of exegesis of the Quran and the second in the series comes the Tradition of the Prophet, Hndilh; at the third stage comes the Fiqh or legal sciences which were developed at an early stage of Islamic history. At that time, the dynamic science of logic, namely al-hadd wa'l- burhan, the evidential logic, was not invented, so that, al-Fiqh had moulded up in the tradition of Aristotelian static syllogistic logic of induction and deduction methodology.

As a consequence, the legal sciences of the Muslims had grown into fixed problematic mas'ala- masail, which actually stalled its dynamism even to the extent of declaring the door of ijtihad closed. This closed circuit of the Muslim way of life and thinking need be drastically remoulded in order to make the Muslim way of life once again dynamic and progressive. 
Moreover, on account of this blind staticness, the learned doctors of Islam looked down upon the Muslim scientists with dubiousness and rejected outright, and still continue to reject, the scientific methodology and scientific logic which they themselves had developed from the base of the holy Quran. This retrogressive attitude must be radically changed before the Muslim way of life and thought could be made really dynamic once again.

Besides, as it is demanded by Islamic spirit, the education system of the Muslims needs be continuously build up with the latest results of the human thought, the practical wisdom and the newer invention and discoveries of experimental sciences in order to make it ceaselessly dynamic befitting the constant curiosity of seeking knowledge from the craddlc to the grave. In the education system, the last must come first and the first come last. The education system, following the principle of al-ibrutu bil-khawatim, i.e. lessons beget from the latest wisdom, needs be continuously moulded and remoulded in order to make it progressive and to set it on the track of continuous progress for the life and thought of humanity,

Last but not least, it must always be reminded that Islam started from religion and ends in religion; hence in matters of education, the Muslim needs take into serious consideration sthe four digital sources of knowledge like other great religions which are known as shariat, tariqat, haqiqat and ma'rifat in Arabic; bibhu, taijasa, pragna and turjya in Buddhuttar Aagam Shastra (cf. Gaudapadacharjya: Agam Shastra, ba Buddhuttar Vedanta, trans. by Bhikshu Shilachar Shastri, Nandankanan Bauddha Vihar, Chittagong, Bangladesh, 1974, pp.1-3).

The same is held by Christianity, Judaism and Vedas only with the difference of words and names ( $c f$ present writer's; 'Typology of Knowledge in the East and the West' in $21^{\text {st }}$ Century challenges for the Global Muslim Community,pp.33-43, Renaissance Foundation publication, Dhaka,2006; the Hindu religious terminology call it Vashonar, Taijasa, Pragna and Turja; in plain Bangla language we call it: Anubhuti, Jukti, Satya and Dibya ganana). Hence, knowledge supplied by the first source, sense perception, which is by itself deceptive must not be taken for granted, but needs be judged by the other three internal sources of knowledge, perceptions in order to maintain the original and abiding religious character of Islamic knowledge. 
Lastly, unity of the scholars in search of truth, and unification of knowledge in search of wisdom, must be animed at, if the humanity is going to realise the Unity of Allah, the Supreme Lord of the Universe (cf. Ibid. pp. 21-23 present winters" The concept of Knowledge in the Quran : as a Pricaple of Unification”).

\section{Conclusion}

To devise a suitable education system for the Muslims is a gigantic task. For its accomplishment, the task has to be first of all (a) to delineate an internationally competitive multiple structure for child education, young man and young woman's education for preparing them to face life, feed-back institutions for the youth and old and research institutions at voluntary levels to watch over smooth functioning, to pick at impediments, initiate suitable changes and ensure dynamism and continuous revision and progress.

Secondly, in the light of the Quran, the primary assumption of Islam has to be grasped, as a universal religion and as such, education is to be seen as next to human life at large. Hence the education system of the Muslims has to be devised with universal Islamic values for humanitarian progress, not merely for the progress of the Muslims alone, but for that of humanity in general . The serial has to be: human life-oriented education system with Islamic values.

Thirdly, in the spirit of the Quranic 'iqrah bismi rabbika 'l-ladhi khalaq, reading by the observation of the mysteries of the creation of the Creator-Sustainer- Rearer-Providence-Lord, the structure of the education system must be based on scientific progress of knowledge in the light of which the. Quran and Sunnah must be read.

Fourthly, the Quranic spirit of Sharh (Resolve) vis-a-vis the code of Law, as dynamism over and against staticness, must be clearly grasped, in that sprit all judgments must be based on the QuranSvnnah-Ijtihad as clearly chalked out by the holy Prophet (sm) as the dynamic processual methodology. In that sence it is suggested that the above Ijtihad- based methodology should replace the medieval Aristotelian syllogistic logic based on the static methodology of Quran-Sunnah-Ijma-Qiyas.

Fifthly, Muslim way of life must be based on Taqwa: fear of the Merciful Lord (Khashiya-r-Rahmana bi 'l-ghaybi) and not on the Ibahat: the lowly level of lawfulness, on which the presently 
conventional Fiqh is based, out of which the salt of taqwa has been taken off to separately constitute Aqaid (Articles of Faith), by the process of which the tarbiyat (manners and morals) of the Muslims has been grossly lowered.

Sixthly, as directed by the Quran and practiced by the holy Prophet (sm) all social and political decisions have to be arrived at by Shura (mutual consultation) and by no means on the basis of loyalty between man to man bai'at).

The holy Prophet took bai 'at at the religious level as fidelity to the Lord and not as a fealty to the ruler or king. He taught us to organise society on the basis of ideal: one ideal one society, two ideals to society; constitute State on the basis of collective pact (mithaqMadinah), and to adopt foreign policy on the basis of negotiated treaty. The holy Prophet (sm) decided all political problems by calling into session Shura Majlis (al-Majlis al-Shura) of the Khas (special') for adopting ruling principles and of the Aam (general) for conducting administration.

The first Khalifah Abu Bakr as-Siddiq followed closely this practice and the second Khalifah Umar al-Faruq constituted. a bicameral Shura Majlis of the Khas and Aam, which were adopted by the Englishmen at Parliament, House of Lords and House of Commons; and it logically led them to democracy and Commonwealth. The holy Prophet (sm) aimed at unfettered welfare of the people in politics and society and as such, shasan, prashasan and janakalyan(kvmb,cÖkvmb, RbKj̈vY) i.e. ruling-administration-people's welfare constituted the Prophet's politics. Why cannot the Muslims adopt the Shura democracy and follow it? The education system of the Muslims must, therefore, be Shura and democracy oriented.

Seventhy, the Muslim education must be a continuously inventive, revisionist and adaptive system with futurist and dynamic outlook aiming at going at the front line of competition at the shortest possible time. It may be well advised to start with a multiple international and national essay competition, with one each first prizes of a substantial value and weight.

Appended herewith a 10 point proposition forwarded by Professor Dr. Muhammad Azhar Ali, ex- Director of the Institute of Education and Research, Dhaka University, as points of emphasis. 
IIUC Studies, Vol. 9

\section{Points to emphasise}

1. To believe in dynamism and continuous revision of education.

2. To develop human life education system with Islamic Values-

3. To enhance the scientific progress of knowledge in the light of the principles of the Quran and Sunnah.

4. To believe in the Muslim way of life based on taqwa, the high loyalty to Allah, and not on the Ibahat the low level of mere lawfulness.

5. All social and political decisions should be taken through mutual consultation. Muslim education must continuosly be inventive, revisionist and adaptive.

6. Regidity in belief should be avoided.

7. Education should be the integration of all good things and ideas of the world.

8. Education should not be left to the people who do not believe in religion.

9. Education should be made open to accept all changes beneficial to mankind and integrated morality. Therefore, should it be left uncared for any more? No, it should be enriched with the ideas of philosophy, enriched with Islamic ideals and equally enriched with experimental wisdom. 